\title{
PATTERN RECOGNITION: MODES OF DEVELOPING MOTOR SKILLS OF ACROBATIC EXERCISES IN BOYS AGED 14
}

\author{
Andrii Bezzub $^{1 \mathrm{ABCD}}$, Oleg Khudoliii ${ }^{1 \mathrm{ABCD}}$, Radoslaw Muszkieta ${ }^{2 \mathrm{ABCD}}$ \\ ${ }^{1}$ H. S. Skovoroda Kharkiv National Pedagogical University \\ ${ }^{2}$ Nicolaus Copernicus University \\ Authors' Contribution: A - Study design; B - Data collection; C - Statistical analysis; D - Manuscript Preparation; E - Funds Collection
}

DOI: $10.17309 / \mathrm{jltm} .2021 .1 .06$

\begin{abstract}
Анотація
The purpose of the study was to determine the impact of exercise modes on the effectiveness of teaching boys aged 14 a cartwheel.

Materials and methods. The study participants were 20 boys aged 14 . The children and their parents were fully informed about all the features of the study and gave their consent to participate in the experiment. To solve the tasks set, the following research methods were used: study and analysis of scientific and methodological literature; pedagogical observation, timing of training tasks; pedagogical experiment, methods of mathematical statistics, discriminant analysis.

Results. The assumption was made about a significant influence of the modes of alternating exercise repetitions and the rest interval on the effectiveness of motor skills development in boys aged 14. The study found that the mode of 6 sets 2 times each with a rest interval of $60 \mathrm{~s}$ is more effective than the mode of 6 sets 1 time each with a rest interval of $60 \mathrm{~s}$ when teaching the first, second, and fourth series of tasks $(\mathrm{p}<0.05)$. The mode of 6 sets 1 time each with a rest interval of $60 \mathrm{~s}$ is more effective when teaching the fifth and sixth series of tasks $(\mathrm{p}<0.05)$.

Conclusions. Discriminant analysis made it possible to determine the impact of the number of repetitions on the effectiveness of developing the cartwheel skill in boys aged 14. Based on the analysis of group centroids, it was found that exercise modes significantly influence the cartwheel skill development in boys aged 14 during physical education classes. The results of group classification show that $100 \%$ of the original grouped observations were classified correctly. Keywords: discriminant analysis, boys, acrobatic exercises, exercise mode, teaching.
\end{abstract}

\section{Introduction}

Physical education at school is aimed at stimulating children's physical development (Elezi et al., 2021; O' Brien et al., 2016; Molina-Garcia et al., 2020), shaping a system of fundamental movements (Samsudin et al., 2021; O’ Brien et al., 2021; Bolger et al., 2018), and increasing motor activity (Listyarini et al., 2021; Hardy et al., 2013; Wibowo et al., 2021).

Physical exercises and their repetition are the main means of physical education aimed at developing motor abilities (Ullrich et al., 2016; Shurley et al., 2020; Dos Santos Cunha et al., 2015) and motor skills (Bonney et al., 2017; Fischer et al., 2018; Magallon et al., 2016).

Motor skills development plays a leading role in schoolchildren's physical education (Ivashchenko et al., 2020; Petrov, et al. 2020; Shevchenko et al., 2020). Based on factor analysis, it was found that the level of proficiency in

(c) Bezzub, A., Khudolii, O., \& Muszkieta, R., 2021. exercises affects the variation of testing results, and motor skills development is a priority in the educational process at school (Ivashchenko et al., 2017; Shevchenko et al., 2020). According to the researchers, one of the factors that influence the effectiveness of motor skills development is the mode of alternating exercises and the rest interval (Iermakov et al., 2021; Ivashchenko et al., 2021; Marchenko et al., 2020).

To determine the effectiveness of motor skills development, regression (Marchenko et al., 2020b), factor (Petrov et al., 2020; Shevchenko et al., 2020; Ivashchenko et al., 2020), and discriminant (Khudolii et al., 2020; Iermakov et al., 2021; Ivashchenko, 2021) analyses are used. Multivariate statistics provide an opportunity to obtain new information about the patterns of motor skills development. Therefore, it is relevant to study the impact of different exercise modes on the effectiveness of teaching 14-year-old schoolchildren acrobatic exercises.

$\begin{array}{ll}\text { JLTM } & \begin{array}{l}\text { Corresponding Author: Khudolii, O., } \\ \text { LLCOVS }\end{array} \\ \text { E-mail: khudolii@hnpu.edu.ua }\end{array}$


The purpose of the study was to determine the impact of exercise modes on the effectiveness of teaching boys aged 14 a cartwheel.

\section{Material and methods}

\section{Study participants}

The study participants were 20 boys aged 14 . The children and their parents were fully informed about all the features of the study and gave their consent to participate in the experiment.

\section{Organization of the study}

To solve the tasks set, the following research methods were used: study and analysis of scientific and methodological literature; pedagogical observation, timing of training tasks; pedagogical experiment, methods of mathematical statistics, discriminant analysis.

The pedagogical experiment examined the influence of 6 and 12 repetitions with a 60-second rest interval during a physical education class on the number of repetitions of training tasks to the $100 \%$ level of proficiency. In the first group $(n=10)$, the boys repeated the tasks 6 sets 1 time each with a rest interval of $60 \mathrm{~s}$, in the second group $(n=10)-6$ sets 2 times each with a rest interval of $60 \mathrm{~s}$.

During teaching, the method of algorithmic instructions was used (Shlemin, 1973). The program of teaching the cartwheel was developed based on the data of Shlemin (1973), Khudolii (2008) and included the following training tasks:

The first series of training tasks - exercises to develop motor abilities

1. From normal standing position, lean forward, touch the floor with the hands and, moving the hands forward on the floor, adopt a push-up position, return to starting position in the same way 3-4 s)

2. Perform push-ups as quickly as possible (5 times in

The second series of training tasks - exercises to master starting and ending positions

1. From standing position with raised arms, step forward and perform a switch leg handstand with assistance

2. Handstand with legs apart with assistance

The third series of training tasks - actions without which it is impossible to perform the target exercise

1. Standing on hands with legs apart with assistance, shift the body weight from one hand to the other

The fourth series of training tasks - teaching the ability to assess movements in space, by time and muscular effort

1. Arriving to handstand quickly with assistance

2. Arriving to handstand slowly with assistance

The fifth series of training tasks - preliminary exercises

1. Arriving to handstand quickly with the wall support

2. Handstand with legs apart with 90-degree rotation with assistance

The sixth series of training tasks - the entire exercise

1. Cartwheel with assistance.

2. Cartwheel without assistance

The next exercise started on condition of correct performance of the previous exercise on three consecutive attempts. The number of repetitions required for correct performance on three consecutive attempts was recorded. The level of proficiency in the exercises was determined by the alternative method: "performed" or "failed". A technically correct performance of the exercise gave the students " 1 " point; a failure to perform the exercise gave them " 0 " entered in the protocol.

\section{Statistical analysis}

The study materials were processed using the IBM SPSS 20 statistical analysis program. Discriminant analysis was conducted. For each canonical discriminant function, the study calculated the following: eigenvalue, variance percentage, canonical correlation, Wilks' lambda, Chi-square. For each step: prior probabilities, Fisher's function coefficients, unstandardized function coefficients, Wilks' lambda for each canonical function.

The study protocol was approved by the Ethical Committee of the University. In addition, the children and their parents or legal guardians were fully informed about all the features of the study, and a signed informed consent document was obtained from all the parents.

\section{Results}

The analysis of mean values shows that statistically significant differences in the number of repetitions are observed in all series of training tasks but the third one ( $\mathrm{p}<0.05$ ). The 14-year-old boys who use the second mode (6 sets 2 times each with a rest interval of $60 \mathrm{~s}$ ) need fewer repetitions to master the movements of the first, second, and fourth series of tasks $(\mathrm{p}<0.05)$. The 14 -year-old boys who use the first mode ( 6 sets 1 time each with a rest interval of $60 \mathrm{~s}$ ) need fewer repetitions to master the movements of the fifth and sixth series of tasks $(\mathrm{p}<0.05)$ (Table 1$)$.

Table 1. Group Statistics. Boys Aged 14

\begin{tabular}{|c|c|c|c|c|c|c|c|c|}
\hline \multirow[t]{2}{*}{$\begin{array}{c}\text { Series } \\
\text { of } \\
\text { tasks }\end{array}$} & \multicolumn{2}{|c|}{$\begin{array}{c}6 \text { repetitions, } \\
\text { rest interval } \\
\text { of } 60 \mathrm{~s}\end{array}$} & \multicolumn{2}{|c|}{$\begin{array}{c}12 \\
\text { repetitions, } \\
\text { rest interval } \\
\text { of } 60 \mathrm{~s} \\
\end{array}$} & \multirow[t]{2}{*}{$\Delta \mathbf{x}$} & \multirow[t]{2}{*}{$\begin{array}{c}\text { Wilks' } \\
\text { Lambda }\end{array}$} & \multirow[t]{2}{*}{$\mathbf{F}$} & \multirow[t]{2}{*}{$\mathbf{p}$} \\
\hline & $\mathbf{M}$ & SD & $\mathbf{M}$ & SD & & & & \\
\hline 1 & 13.9 & 2.33 & 8.0 & 2.45 & 5.9 & .372 & 30.446 & .000 \\
\hline 2 & 10.5 & 2.72 & 6.6 & 2.84 & 3.9 & .646 & 9.855 & .006 \\
\hline 3 & 6.2 & 1.81 & 7.9 & 3.54 & -1.7 & .908 & 1.825 & .193 \\
\hline 4 & 9.9 & 1.66 & 4.8 & 1.62 & 5.1 & .272 & 48.266 & .000 \\
\hline 5 & 5.8 & 1.14 & 7.7 & 1.25 & -1.9 & .587 & 12.642 & .002 \\
\hline 6 & 6.0 & 0.66 & 9.4 & 2.67 & -3.4 & .542 & 15.211 & .001 \\
\hline
\end{tabular}

To determine the impact of different modes of exercises on the level of proficiency, discriminant analysis was conducted (Tables 2-6). A necessary condition for discriminant analysis is the homogeneity of variances and covariances of data. The Box's $M$ test confirms the assumption about the homogeneity of variances and covariances (Table 2).

The first canonical function explains $100 \%$ of the results variation, which indicates its high informativity $(r=0.949)$ (see Table 3). The analysis of the canonical function shows its sta- 
Table 2. Box's M Test for Testing Equal Population Covariance Matrices (DA)

\begin{tabular}{llr}
\hline & Box's $\mathbf{M}$ & $\mathbf{4 7 . 0 0 3}$ \\
\hline F & Approx. & 1.408 \\
df1 & 21 \\
df2 & 1191.671 \\
Sig. & .104 \\
\hline
\end{tabular}

Table 3. Eigenvalues for Developing Discriminant Model (Canonical Correlation). Boys Aged 14

\begin{tabular}{ccccc}
\hline Function & Eigenvalue & $\begin{array}{c}\text { \% of } \\
\text { Variance }\end{array}$ & $\begin{array}{c}\text { Cumulative } \\
\%\end{array}$ & $\begin{array}{c}\text { Canonical } \\
\text { Correlation }\end{array}$ \\
\hline 1 & 9.084 & 100.0 & 100.0 & .949 \\
\hline
\end{tabular}

Table 4. Outcomes of Calculated Wilks' Lambda of Discriminant Function. Boys Aged 14

\begin{tabular}{ccccc}
\hline Test of Function(s) & Wilks' Lambda & Chi-square & df & Sig. \\
\hline 1 & .099 & 34.665 & 6 & .000 \\
\hline
\end{tabular}

tistical significance $(\lambda 1=0.099 ; \mathrm{p} 1=0.001)$. The first function has a high discriminative ability and value in interpretation of the general population (Table 4).

The standardized canonical discriminant function coefficients make it possible to determine the ratio of the

Table 5. Standardized Canonical Discriminant Function Coefficients. Boys Aged 14

\begin{tabular}{cc}
\hline Series of tasks & Function \\
\cline { 2 - 2 } & \multicolumn{1}{c}{$\mathbf{1}$} \\
\hline 1 & -.475 \\
2 & -.099 \\
3 & .541 \\
5 & -.810 \\
6 & .185 \\
\hline
\end{tabular}

Table 6. Structure Matrix. Boys Aged 14

\begin{tabular}{cc}
\hline Series of tasks & Function \\
\cline { 2 - 2 } & $\mathbf{1}$ \\
\hline 1 & -.543 \\
6 & -.432 \\
5 & .305 \\
& .278 \\
2 & \\
3 & -.246 \\
& .106 \\
\hline
\end{tabular}

Table 7. Canonical Discriminant Function Coefficients (Unstandardized coefficients)

\begin{tabular}{cc}
\hline Series of tasks & Function \\
\cline { 2 - 2 } & $\mathbf{1}$ \\
\hline 1 & -.198 \\
2 & -.035 \\
4 & .192 \\
5 & -.494 \\
6 & .155 \\
(Constant) & .374 \\
\end{tabular}

contribution of variables to the function result. The results of the fourth, sixth, and first series of training tasks make the largest contribution to the first canonical function. The above indicates that the exercises of the fourth, sixth, and first series of training tasks are the most sensitive to the number of repetitions in boys aged 14 (Table 5).

The structure canonical discriminant function coefficients are the coefficients of correlation between the variables and the function. Thus, the function is most closely connected with the number of repetitions of exercises of the fourth, first, and sixth series of training tasks ( $r 4=-0.543 ; \mathrm{r} 1$ $=-0.432 ; \mathrm{r} 6=0.305)$ (Table 6$)$.

The coordinates of centroids for two groups make it possible to interpret the canonical function in relation to the role in classification. At the positive pole is a centroid for the exercise mode of 12 repetitions, at the negative - a centroid for the exercise mode of 6 repetitions (see Table 8, Fig. 1, 2 ). This indicates a significant difference in the impact of exercise repetition modes on the number of repetitions required for motor skills development in boys aged 14 during physical education classes. The results of group classification

Table 8. Functions at Group Centroids. Boys Aged 14

\begin{tabular}{lc}
\hline \multicolumn{1}{c}{ Exercise Mode } & Function \\
\cline { 2 - 2 } & $\mathbf{1}$ \\
\hline $1-6$ repetitions, rest interval of $60 \mathrm{~s}$ & -2.859 \\
$2-12$ repetitions, rest interval of $60 \mathrm{~s}$ & 2.859 \\
\hline
\end{tabular}

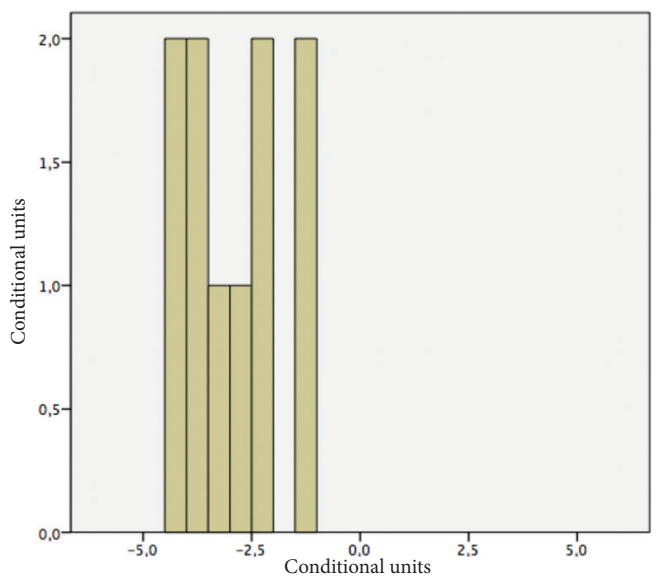

Fig. 1. Graphic representation of classification results: 6 repetitions, rest interval of $60 \mathrm{~s}$

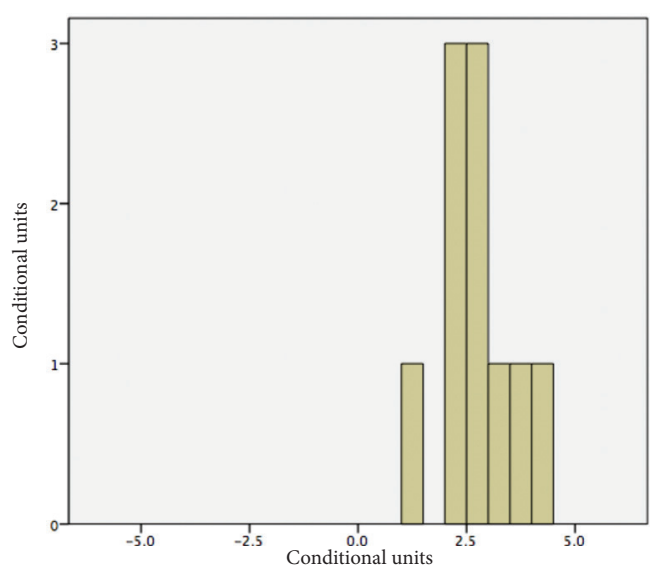

Fig. 2. Graphic representation of classification results: 12 repetitions, rest interval of $60 \mathrm{~s}$ 
Table 9. Classification Results ${ }^{\mathrm{a}, \mathrm{c}}$

\begin{tabular}{|c|c|c|c|c|c|}
\hline & & \multirow{2}{*}{ Exercise Mode } & \multicolumn{2}{|c|}{ Predicted Group Membership } & \multirow{2}{*}{ Total } \\
\hline & & & 1 & 2 & \\
\hline \multirow[t]{4}{*}{ Original } & Count & $1-6$ repetitions, rest interval of $60 \mathrm{~s}$ & 10 & 0 & 10 \\
\hline & & $2-12$ repetitions, rest interval of $60 \mathrm{~s}$ & 0 & 10 & 10 \\
\hline & $\%$ & $1-6$ repetitions, rest interval of $60 \mathrm{~s}$ & 100.0 & .0 & 100.0 \\
\hline & & $2-12$ repetitions, rest interval of $60 \mathrm{~s}$ & .0 & 100.0 & 100.0 \\
\hline \multirow[t]{4}{*}{ Cross-validated $^{\mathrm{b}}$} & Count & $1-6$ repetitions, rest interval of $60 \mathrm{~s}$ & 10 & 0 & 10 \\
\hline & & $2-12$ repetitions, rest interval of $60 \mathrm{~s}$ & 1 & 9 & 10 \\
\hline & $\%$ & $1-6$ repetitions, rest interval of $60 \mathrm{~s}$ & 100.0 & .0 & 100.0 \\
\hline & & $2-12$ repetitions, rest interval of $60 \mathrm{~s}$ & 10.0 & 90.0 & 100.0 \\
\hline
\end{tabular}

a. $100.0 \%$ of original grouped cases correctly classified. b. Cross validation is done only for those cases in the analysis. In cross validation, each case is classified by the functions derived from all cases other than that case. c. $95.0 \%$ of cross-validated grouped cases correctly classified.

show that $100.0 \%$ of the original grouped observations were classified correctly (Table 9). Based on the discriminant function coefficients and centroids, it is possible to calculate the number of repetitions for mastering the motor skill (Table 7).

\section{Discussion}

The assumption was made about a significant influence of the modes of alternating exercise repetitions and the rest interval on the effectiveness of motor skills development in boys aged 14. The study found that the mode of 6 sets 2 times each with a rest interval of $60 \mathrm{~s}$ is more effective than the mode of 6 sets 1 time each with a rest interval of $60 \mathrm{~s}$ when teaching the first, second, and fourth series of tasks $(\mathrm{p}<0.05)$. The mode of 6 sets 1 time each with a rest interval of $60 \mathrm{~s}$ is more effective when teaching the fifth and sixth series of tasks $(p<0.05)$.

The results presented confirm the data of Iermakov et al. (2021), Ivashchenko et al. (2015, 2017), Marchenko et al. (2020) about the influence of exercise modes on the effectiveness of motor skills development in schoolchildren.

The study confirmed the possibility of using a discriminant function to assess the effectiveness of different modes of physical exercises when teaching acrobatic exercises, as the verification of canonical functions indicates their statistical significance. It was found that $100.0 \%$ of the original grouped observations were classified correctly. In other studies on motor skills development, there was a 78-85\% level of classification of original grouped observations (Khudolii et al., 2020; Iermakov et al., 2021; Ivashchenko, 2020). Therefore, the obtained data confirm the effectiveness of discriminant analysis for identifying the patterns of motor skills development.

Thus, the following exercise modes can be recommended to teach boys aged 14 the cartwheel:

Series $1-4-6$ sets 2 times each with a rest interval of $60 \mathrm{~s}$; Series 5-6-6 sets 1 time each with a rest interval of $60 \mathrm{~s}$.

\section{Conclusions}

Discriminant analysis made it possible to determine the impact of the number of repetitions on the effectiveness of developing the cartwheel skill in boys aged 14 .

Based on the analysis of group centroids, it was found that exercise modes significantly influence the cartwheel skill development in boys aged 14 during physical education classes. The results of group classification show that $100 \%$ of the original grouped observations were classified correctly.

The study found that the mode of 6 sets 2 times each with a rest interval of $60 \mathrm{~s}$ is more effective than the mode of 6 sets 1 time each with a rest interval of $60 \mathrm{~s}$ when teaching the first, second, and fourth series of tasks. The mode of 6 sets 1 time each with a rest interval of $60 \mathrm{~s}$ is more effective when teaching the fifth and sixth series of tasks.

\section{Acknowledgment}

The study was carried out according to the research plan of the Department of Theory and Methodology of Physical Education of H. S. Skovoroda Kharkiv National Pedagogical University within the topic "Theoretical and methodological foundations of modeling the learning process and motor abilities development in children and adolescents" (20132022) (state registration number 0112U002008).

\section{Conflict of interest}

The authors declare that there is no conflict of interest.

\section{References}

Elezi, A., Elezi, G., Gontarev, S., \& Georgiev, G. (2021). Secular Trends in Anthropometric Characteristics and Health-Related Physical Fitness in Macedonian Children: the Makfit Studies. Teoriâ ta Metodika Fizičnogo Vihovannâ, 21(1), 12-18. https://doi.org/10.17309/tmfv.2021.1.02

O’Brien, W., Belton, S., \& Issartel, J. (2016). The relationship between adolescents' physical activity, fundamental movement skills and weight status. Journal of Sports Sciences, 34(12), 1159-1167. Scopus. https://doi.org/10.1080/02640414.2015.1096017

Molina-Garcia, P., Mora-Gonzalez, J., Migueles, J. H., Rodriguez-Ayllon, M., Esteban-Cornejo, I., CadenasSanchez, C., Plaza-Florido, A., Gil-Cosano, J. J., PelaezPerez, M. A., Garcia-Delgado, G., Vanrenterghem, J., \& Ortega, F. B. (2020). Effects of Exercise on Body Posture, Functional Movement, and Physical Fitness in Children With Overweight/Obesity. Journal of Strength and Conditioning Research, 34(8), 2146-2155. Scopus. https://doi.org/10.1519/JSC.0000000000003655 
Samsudin, S., Setiawan, I., Taufik, M., \& Solahuddin, S. (2021). Volleyball Fundamental Movement Learning Model in Primary School. Teoriâ ta Metodika Fizičnogo Vihovannâ, 21(3), 194-199. https://doi.org/10.17309/tmfv.2021.3.02

O'Brien, W., Philpott, C., Lester, D., Belton, S., Duncan, M. J., Donovan, B., Chambers, F., \& Utesch, T. (2021). Motor competence assessment in physical education-convergent validity between fundamental movement skills and functional movement assessments in adolescence. Physical Education and Sport Pedagogy. Scopus. https://doi.org/10.1080/17408989.2021.1990241

Bolger, L. E., Bolger, L. A., Neill, C. O., Coughlan, E., O’Brien, W., Lacey, S., \& Burns, C. (2018). Age and sex differences in fundamental movement skills among a cohort of Irish school children. Journal of Motor Learning and Development, 6(1), 81-100. Scopus. https://doi.org/10.1123/jmld.2017-0003

Listyarini, A., Alim, A., Oktaviani, A., Putro, K., Kristiyanto, A., Margono, A., \& Pratama, K. (2021). The Relations of Using Digital Media and Physical Activity with the Physical Fitness of 4th and 5th Grade Primary School Students. Teoriâ ta Metodika Fizičnogo Vihovannâ, 21(3), 281-287. https://doi.org/10.17309/tmfv.2021.3.12

Hardy, L. L., Barnett, L., Espinel, P., \& Okely, A. D. (2013). Thirteen-year trends in child and adolescent fundamental movement skills: 1997-2010. Medicine and Science in Sports and Exercise, 45(10), 1965-1970. Scopus. https://doi.org/10.1249/MSS.0b013e318295a9fc

Wibowo, R., Budiman, D., Sumarno, G., Stephani, M. R., \& Putri, W. (2021). Is physical activity level in physical education lesson related to fundamental movement skills at elementary schools? International Journal of Human Movement and Sports Sciences, 9(4), 31-37. Scopus. https://doi.org/10.13189/saj.2021.091306

Ullrich, B., Pelzer, T., Oliveira, S., \& Pfeiffer, M. (2016). Neuromuscular Responses to Short-Term Resistance Training with Traditional and Daily Undulating Periodization in Adolescent Elite Judoka. Journal of Strength and Conditioning Research, 30(8), 2083-2099. Scopus. https://doi.org/10.1519/JSC.0000000000001305

Shurley, J. P., Ednie, A. J., \& Rudebeck, T. J. (2020). Strength and Conditioning Practices of Head Coaches of Male and Female Interscholastic Sport Teams. Journal of Strength and Conditioning Research, 34(7), 1894-1902. Scopus. https://doi.org/10.1519/JSC.0000000000003624

Dos Santos Cunha, G., Sant'anna, M. M., Cadore, E. L., De Oliveira, N. L., Dos Santos, C. B., Pinto, R. S., \& ReischakOliveira, A. (2015). Physiological adaptations to resistance training in prepubertal boys. Research Quarterly for Exercise and Sport, 86(2), 172-181. Scopus. https://doi.org/10.1080/02701367.2014.982782

Bonney, E., Jelsma, L., Ferguson, G., \& Smits-Engelsman, B. (2017). Learning better by repetition or variation? Is transfer at odds with task specific training? PLOS ONE, 12(3). https://doi.org/10.1371/journal.pone.0174214

Fischer, U., Suggate, S., Schmirl, J., \& Stoeger, H. (2018). Counting on fine motor skills: Links between preschool finger dexterity and numerical skills. DEVELOPMENTAL SCIENCE, 21(4). https://doi.org/10.1111/desc.12623

Magallon, S., Narbona, J., \& Crespo-Eguilaz, N. (2016). Acquisition of Motor and Cognitive Skills through
Repetition in Typically Developing Children. PLOS ONE, 11(7). https://doi.org/10.1371/journal.pone.0158684

Ivashchenko, O., Berezhna, H., \& Cieślicka, M. (2020). Motor Skills in the Structure of Physical Fitness of 7-Year-Old Boys. Journal of Learning Theory and Methodology, 1(1), 14-19. https://doi.org/10.17309/jltm.2020.1.02

Petrov, D., Khudolii, O., \& Cieślicka, M. (2020). Motor Skills: Motor Fitness Structure of 9-Year-Old Boys. Journal of Learning Theory and Methodology, 1(2), 58-63. https://doi.org/10.17309/jltm.2020.2.02

Shevchenko, T., Khudolii, O., \& Potop, V. (2020). Motor Skills in Physical Fitness Structure of 8-Year-Old Girls. Journal of Learning Theory and Methodology, 1(2), 64-69. https://doi.org/10.17309/jltm.2020.2.03

Ivashchenko, O. V., Iermakov, S. S., Khudolii, O. M., Cretu, M., \& Potop, V. (2017). Level of physical exercises' mastering in structure of 11-13 yrs age boys' motor fitness. Pedagogics, psychology, medical-biological problems of physical training and sports, (5), 236-243.

Iermakov, S., Ivashchenko, O., Khudolii, O., Chernenko, S., Veremeenko, V., \& Zelenskyi, B. (2021). Pattern Recognition: Impact of Exercises Modes on Developing a Small Ball Throwing Skill in Boys Aged 8. Teoriâ ta Metodika Fìičnogo Vihovannâ, 21(1), 77-83. https://doi.org/10.17309/tmfv.2021.1.10

Ivashchenko, O., Iermakov, S., \& Khudolii, O. (2021). Modeling: ratio between means of teaching and motor training in junior school physical education classes. Pedagogy of Physical Culture and Sports, 25(3), 194-201. https://doi.org/10.15561/26649837.2021.0308

Marchenko, S., \& Kovalenko, K. (2020a). Optimization of Teaching Boys Aged 10 Mae-Geri (Front Kick) Technique in Kyokushin Karate. Journal of Learning Theory and Methodology, 1(1), 33-39. https://doi.org/10.17309/jltm.2020.1.05

Ivashchenko, O. V., \& Kapkan, O. O. (2015). Simulation of process of 14-15 years old girls' training of light athletic and gymnastic exercises. Pedagogics, psychology, medicalbiological problems of physical training and sports, (8), 32-40.

Khudolii, O., Kapkan, O., Harkusha, S., Marchenko, S., \& Veremeenko, V. (2020). Motor Skills Development: Optimization of Teaching Boys Aged 15 Press Headstand and Handstand. Teoriâ ta Metodika Fizičnogo Vihovannâ, 20(1), 42-48. https://doi.org/10.17309/tmfv.2020.1.06

Marchenko, S., \& Taranenko, O. (2020b). Managing the Effectiveness of Teaching Boys Aged 10 MawashiGeri (Roundhouse Kick) Technique in Kyokushin Karate. Teoriâ ta Metodika Fizičnogo Vihovannâ, 20(4), 262-268. https://doi.org/10.17309/tmfv.2020.4.10

Ivashchenko, O. (2020). Research Program: Modeling of Motor Abilities Development and Teaching of Schoolchildren. Teoriâ ta Metodika Fizičnogo Vihovannâ, 20(1), 32-41. https://doi.org/10.17309/tmfv.2020.1.05

Khudolii, O.M. (2008). Osnovy metodyky vykladannia himnastyky: Navch. posibnyk. U 2-kh tomakh. 4-e vyd., vypr. i dop. Kharkiv: «OVS», T. 1, 408.

Shlemin, A.M. (1973). Iunyi gimnast. M.: Fizkultura i sport, 376. 


\title{
РОЗПІЗНАННЯ ОБРАЗІВ: РЕЖИМИ ФОРМУВАННЯ РУХОВИХ НАВИЧОК АКРОБАТИЧНИХ ВПРАВ ХЛОПЦІВ 14 РОКІВ
}

\author{
Андрій Беззуб ${ }^{1 \mathrm{ABCD}}$, Олег Худолій ${ }^{1 \mathrm{ABCD}}$, Радослав Мушкета ${ }^{2 \mathrm{ABCD}}$ \\ ${ }^{1}$ Харківський національний педагогічний університет імені Г.С. Сковороди \\ ${ }^{2}$ Університет Миколи Коперника \\ Авторський вклад: А - дизайн дослідження; В - збір даних; C - статаналіз; D - підготовка рукопису; Е - збір коштів \\ Реферат. Статья: 6 с., 2 табл., 2 рис., 23 джерела.
}

Мета дослідження - визначити вплив режимів виконання вправ на ефективність процесу навчання перевороту убік хлопців 14 років.

Матеріали і методи. У дослідженні прийняли участь 20 хлопців 14 років. Діти та їхні батьки були інформовані про всі особливості дослідження і дали згоду на участь в експерименті. Для вирішення поставлених завдань були використані методи дослідження: вивчення та аналіз науково-методичної літератури; педагогічне спостереження, хронометраж навчальних завдань; педагогічний експеримент, методи математичної статистики, дискримінантний аналіз.

Результати. Приймається припущення про суттєвий вплив режимів чергування повторень вправ та інтервалу відпочинку на ефективність формування рухових навичок у хлопців 14 років. Встановлено що режим 6 підходів по 2 рази з інтервалом відпочинку 60 с має більшу ефективність ніж режим 6 підходів по 1 разу з інтервалом відпочинку 60 с у процесі навчання першої, другої та четвертої серії завдань ( $\mathrm{p}<0,05)$. Режим 6 підходів по 1 разу з інтервалом відпочинку 60 с має більшу ефективність у процесі навчання п'ятої та шостої серій завдань $(\mathrm{p}<0,05)$.

Висновки. Дискримінантний аналіз дозволив визначити вплив кількості повторень на ефективність формування навички виконання перевороту убік хлопців 14 років. На основі аналізу центроїдів груп визначено, що режими виконання вправ мають суттєвий вплив на процес формування навички виконання перевороту убік хлопців 14 років на уроках фізичної культури. Результати класифікації груп показують, що 100 \% вихідних згрупованих спостережень класифіковано вірно.

Ключові слова: дискримінантний аналіз, хлопці, акробатичні вправи, режим виконання вправ, навчання.

Information about the authors:

Bezzub Andrii: andbezzub55@gmail.com; https://orcid.org/0000-0001-5343-2104; H. S. Skovoroda Kharkiv National Pedagogical University, Alchevskikh St, 29, Kharkiv, 61002, Ukraine

Khudolii Oleg: khudolii@hnpu.edu.ua; https://orcid.org/0000-0002-5605-9939; H. S. Skovoroda Kharkiv National Pedagogical University, Department of Theory and Methodology of Physical Education, Alchevskikh St, 29, Kharkiv, 61002, Ukraine

Muszkieta Radosław: muszkieta@umk.pl; https://orcid.org/0000-0001-6057-1583; Nicolaus Copernicus University; Faculty of Earth Sciences, Jurija Gagarina St,11, 87-100 Toruń, Poland

Cite this article as: Bezzub, A., Khudolii, O., \& Muszkieta, R. (2021). Pattern Recognition: Modes of Developing Motor Skills of Acrobatic Exercises in Boys Aged 14. Journal of Learning Theory and Methodology, 2(1), 41-46. https://doi.org/10.17309/jltm.2021.1.06

Received: 27.01.2021. Accepted: 20.02.2021. Published: 26.02.2021

This work is licensed under a Creative Commons Attribution 4.0 International License (http://creativecommons.org/licenses/by/4.0). 